\title{
Protective Effect of Salvianolic Acid B in Acetic Acid-Induced Experimental Colitis in a Mouse Model
}

\author{
Mydhili Govindarasu ${ }^{1}\left({ }^{(}\right.$, Mohammad Azam Ansari $^{2}{ }^{(0}$, Mohammad N. Alomary $^{3}{ }^{(}$, Sami AlYahya $^{3}$, \\ Saad Alghamdi ${ }^{4}{ }^{\circ}$, Azzah M. Bannunah ${ }^{5}$, Mazen Almehmadi ${ }^{6}{ }^{\circ}$, Pari Abirami ${ }^{7}$, Ekambaram Gayathiri ${ }^{8} \mathbb{C}^{\circ}$, \\ Mariyappan Palani ${ }^{1}$, Govindasamy Rajakumar ${ }^{9} \mathbb{C}$, Muthu Thiruvengadam ${ }^{10, *}$ and Manju Vaiyapuri ${ }^{1, *}$
}

1 Molecular Oncology Laboratory, Department of Biochemistry, Periyar University, Salem 636011, Tamil Nadu, India; mydhilibc12@gmail.com (M.G.); mariyappanjp@gmail.com (M.P.)

2 Department of Epidemic Disease Research, Institute for Research \& Medical Consultations (IRMC), Imam Abdulrahman Bin Faisal University, P.O. Box 1982, Dammam 31441, Saudi Arabia; maansari@iau.edu.sa

3 National Centre for Biotechnology, King Abdulaziz City for Science and Technology (KACST), P.O. Box 6086, Riyadh 11442, Saudi Arabia; malomary@kacst.edu.sa (M.N.A.); salyahya@kacst.edu.sa (S.A.)

4 Laboratory Medicine Department, Faculty of Applied Medical Sciences, Umm Al-Qura University, P.O. Box 715, Makkah 21955, Saudi Arabia; ssalghamdi@uqu.edu.sa

5 Department of Basic Sciences, Common First Year Deanship, Umm Al-Qura University, P.O. Box 715, Makkah 21955, Saudi Arabia; ambannunah@uqu.edu.sa

check for updates

Citation: Govindarasu, M.; Ansari, M.A.; Alomary, M.N.; AlYahya, S.; Alghamdi, S.; Bannunah, A.M.; Almehmadi, M.; Abirami, P.; Gayathiri, E.; Palani, M.; et al. Protective Effect of Salvianolic Acid B in Acetic Acid-Induced Experimental Colitis in a Mouse Model. Processes 2021, 9, 1589. https://doi.org/ $10.3390 /$ pr9091589

Academic Editors: Luigi Menghini, Claudio Ferrante, Pau Loke Show and Yunfei Du

Received: 11 July 2021

Accepted: 2 September 2021

Published: 5 September 2021

Publisher's Note: MDPI stays neutral with regard to jurisdictional claims in published maps and institutional affiliations.

Copyright: () 2021 by the authors. Licensee MDPI, Basel, Switzerland. This article is an open access article distributed under the terms and conditions of the Creative Commons Attribution (CC BY) license (https:// creativecommons.org/licenses/by/ $4.0 /)$.
6 Department of Clinical Laboratory Sciences, College of Applied Medical Sciences, Taif University, P.O. Box 11099, Taif 21944, Saudi Arabia; Dr.mazen.ma@gmail.com

7 Department of Botany, Seethalakshmi Achi College for Women, Pallathur, Sivagangai 630107, Tami Nadu, India; abirami.harini2011@gmail.com

8 Guru Nanak College (Autonomous), Chennai 600042, Tamil Nadu, India; gay3purush@gmail.com

9 Collaborative Innovation Center for Advanced Organic Chemical Materials Co-Constructed by the Province and Ministry, Ministry of Education Key Laboratory for the Synthesis and Application of Organic Functional Molecules and College of Chemistry and Chemical Engineering, Hubei University, Wuhan 430062, China; microlabsraj@gmail.com

10 Department of Applied Bioscience, College of Life and Environmental Sciences, Konkuk University, Seoul 05029, Korea

* Correspondence: muthu@konkuk.ac.kr (M.T.); manjucb11@gmail.com (M.V.)

Abstract: In its prominent experimental studies salvianolic acid B (Sal B) is novel because of its well-defined, common physiological effects, which include anti-inflammatory, anti-depressant, cardioprotective, DNA protective, neuroprotective and hepatoprotective activity in experimental animals. Initially, Sal B was studied for its anti-inflammatory properties, used as a remedy for a wide range of disease conditions, but its specific efficacy on inflammatory bowel disease is still unclear. The aim of this current study was to understand the therapeutic potential of Sal B in an acetic acid (AA) - triggered experimental mouse colitis model. Colitis was triggered by intrarectal injection of $5 \% \mathrm{AA}$, and then laboratory animals were given Sal B $(10,20$ and $40 \mu \mathrm{g} / \mathrm{kg})$ for seven days. The ulcerated colonic mucosa was assessed by clinical experiment, macroscopical, biological and histopathological analysis. The results showed depleted SOD, CAT, GSH levels and consequential elevated MPO and MDA levels and aberrant crypt foci and mast cells were seen in the AA-induced colonic mucosa of experimental animals. The data obtained from this study demonstrate that a dose of $40 \mu \mathrm{g} / \mathrm{kg}$ showed an efficacious anti-ulcer effect against AA-induced experimental colitis. Based on its antioxidant efficacy, Sal B may therefore be useful as a therapeutic approach for ulcerative colitis.

Keywords: ulcerative colitis; salvianolic acid B; acetic acid; myeloperoxidase; ACF; mast cells

\section{Introduction}

Ulcerative colitis (UC) is a widespread significant complication of irritable bowel syndrome and chronic gastrointestinal tract immunological disorder that causes inexorable 
ulceration, tenesmus, diarrhea, bloody stools, inflammation in the intestine and colon and mucosal tissue damage [1-3]. Inflammatory bowel disease (IBD) affected about 2.5 million people in the United States in 2020. By 2030, it is expected that the number of people living with IBD in the United States will have increased to about 3.5 million [4,5]. Ulcerative colitisrelated malignancy has some characteristics, including abdominal pain, anemia, diarrhea, slightly raised plaques, and villous adenomas that become malignant [6,7]. However, the etiology of IBD is not clearly understood. The current therapeutic approaches are known for being ineffective at both inducing injury recovery and stopping it from continuing to spread. The inflamed mucosa produces reactive oxygen species (ROS), which may play a role in the observed increased risk of colorectal cancer [8]. The body's antioxidant defense mechanisms protect tissues from ROS under normal conditions. The over-expression of free radicals acts as a severe contributor to the pathological events of ulcerative colitis [9]. Under physiological circumstances, a balanced condition between free radicals and antioxidants is maintained, which is disrupted during pathological conditions $[10,11]$. Excess levels of ROS lead to oxidative stress and, thus damage to DNA due to variations among innate exogenous antioxidants. Sal B (Figure 1) is a bioactive phenolic compound extracted from Salvia miltiorrhiza roots; these compounds mostly have antioxidant and free radical scavenging activity [12]. Sal B's biological properties were documented to include antiinflammatory, cardioprotective [13], neuroprotective [14], osteoporosis protective [15] and hepatoprotective effects [16]. Our current research aimed to assess the therapeutic potential of Sal B against AA-induced experimental colitis in a mouse model.

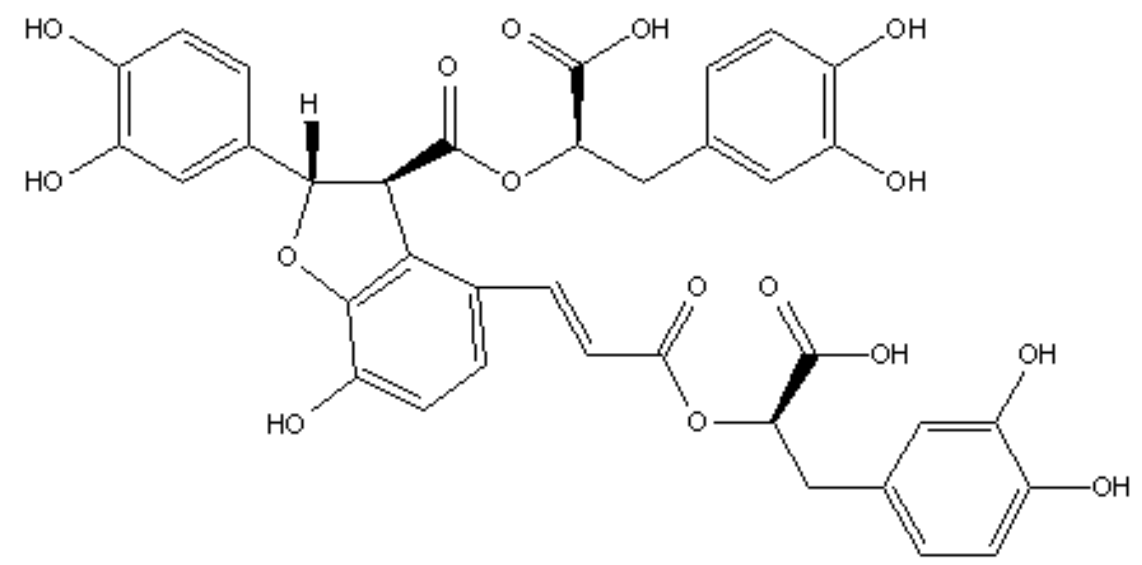

Figure 1. The molecular structure of Sal B.

\section{Materials and Methods}

\subsection{Chemicals}

Salvianolic acid B was obtained from Sigma-Aldrich Chemical Company (St. Louis, MO, USA). Acetic acid, ketamine, phosphate buffer saline, hydrogen peroxide, ethylene diamine tetraacetic acid (EDTA), nitroblue tetrazolium (NBT), ethanol (EtOH), hexadecyltrimethylammonium bromide $(\mathrm{CTAB})$, methylene blue and all other chemicals were obtained from Sigma-Aldrich Chemical Company (Bangalore, India) and of analytical or reagent grade.

\subsection{Animals and Ethical Approval}

Male Swiss Albino mice weighed 20-25 g approximately; (8-9 weeks old) were purchased from Sri Venkateshwara Enterprises (Bangalore, India). Animals were maintained in a sterile environment $\left(25^{\circ} \mathrm{C}, 12 \mathrm{hr}\right.$ daylight/dark period). Mice had free access to feed pellets and were able to drink water whenever they desired. The Ethics Commission of Periyar University approved this study (approval number: 1085/ac/07/CPCSEA/PUIAEC/March2014/06). 


\subsection{Induction of Experimental Colitis in Mice}

The acute UC model was induced by the administration of 5\% AA [17]. Following $24 \mathrm{~h}$ fasting, animals were gently anesthetized with ketamine or xylazine $(80 / 10 \mathrm{mg} / \mathrm{kg})$ intraperitoneally. A $3.5 \mathrm{~F}$ catheter was subsequently inserted into the stomach with the tip placed $4 \mathrm{~cm}$ from the rectum. One $\mathrm{mL}$ of AA ( $5 \% \mathrm{v} / \mathrm{v})$ with $0.9 \%$ saline was used to induce colitis in the colon's lumen along with a sustained supine Trendelenburg position for $30 \mathrm{~s}$ to avoid any outflow of the intra-colonic AA dose. Control mice in this study were treated by a similar protocol but given only $0.9 \%$ saline.

\subsection{Animals}

Animals were randomly divided into five groups $(n=6)$ : (1) Control ( $0.9 \%$ saline); (2) AA-treated mice (50 $\mu \mathrm{L} / \mathrm{kg}$ body weight per day); (3) AA + Sal B $10 \mu \mathrm{g} / \mathrm{kg}$; (4) AA + Sal B $20 \mu \mathrm{g} / \mathrm{kg}$; (5) AA + Sal B $40 \mu \mathrm{g} / \mathrm{kg}$ body weight per day (Figure 2).

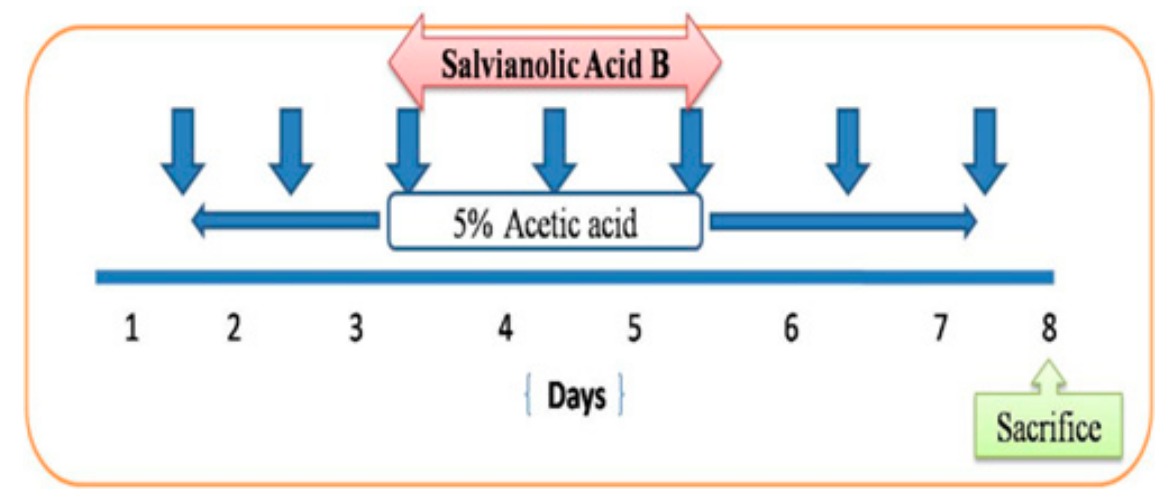

Figure 2. Experimental design. Mice in the AA and Sal B group received an intrarectal dose of $1 \mathrm{~mL}$ of $5 \% \mathrm{AA}$, whereas the normal control group animals were given $1 \mathrm{~mL}$ of sterile saline. On day 8 blood and colonic tissues were collected.

\subsection{Macroscopic Damage Score}

The colon was dissected, opened longitudinally as well as the injury score was determined by specific characteristics previously described [18]:

$0=$ No damage

$1=$ localized hyperemia but no ulcers

$2=$ linear ulcers with no significant inflammation

$3=$ linear ulcers with inflammation at one site

$4=$ two or more sites of ulceration \& inflammation

$5=$ two or more sites of ulceration with major inflammation $>1 \mathrm{~cm}$ along the length of the colon.

For calculation of values for morphological scores, individual scores given by the predicted values were averaged and the mean of the scores were determined and are given as mean \pm SEM.

\subsection{Histopathological Evaluation of Colitis}

For histopathological examination, the colon was separated from the proximal rectum, removed from adherent tissues, and washed in PBS. The colonic tissues were fixed in $10 \%$ formalin, dehydrated with a sequential increase of $\mathrm{EtOH}$ concentration, fixed within paraffin, and then sectioned. Sections were fixed on slides, cleaned, hydrated, and stained with hematoxylin at a thickness of $5 \mu \mathrm{m}$. The histopathological scoring was evaluated as per the earlier reported method [19], as follows: (0) no abnormality; (i) mild but unequivocal increase; (ii) squatty leukocyte percolation; (iii) neutrophils in the epithelium, hardening of the colon parietes, (iv) excess of neutrophils in part of the crypt, lack of goblet cells, 
elevated vascular density, unequivocal erosion ulcer or granulation tissue and hardening of the colon parietes.

\subsection{Biochemical Measurements}

The animals were sacrificed by cervical dislocation under anesthesia ketamine/xylazine $(80 / 10 \mathrm{mg} / \mathrm{kg})$ administered intraperitoneally, and the distal colon sections were collected, stored at $-80^{\circ} \mathrm{C}$ until further examination. 1 to $2 \mathrm{~g}$ of distal colon tissues was collected for further investigation. The colon sections were washed, cut into smaller pieces, and homogenized in $10 \mathrm{mM}$ of ice-cold Tris- $\mathrm{HCl}$ buffer ( $\mathrm{pH}$ 7.1) to obtain tissue homogenate. The samples were centrifuged at $4000 \mathrm{rpm}$ for $15 \mathrm{~min}$ at $4{ }^{\circ} \mathrm{C}$ in a cooling centrifuge (REMI micro refrigerated centrifuge, Chennai, India), and the colonic tissue homogenate was utilized for biochemical measurements $[20,21]$.

\subsection{Measurement of CAT Activity in Colon Tissues}

Catalase (CAT) activity in intestinal colonic tissue supernatants was measured using a spectrophotometric technique developed by Aebi [22]. $20 \mu \mathrm{L}$ of the homogenate was taken and mixed with $2 \mathrm{~mL}$ of PBS ( $50 \mathrm{mM}$, pH 7.0) including $10 \mathrm{mM} \mathrm{H}_{2} \mathrm{O}_{2}$. Catalase activity is defined as the quantity of enzyme needed to degrade $1 \mathrm{nmol}$ of $\mathrm{H}_{2} \mathrm{O}_{2}$ per minute at $25^{\circ} \mathrm{C}$ and $\mathrm{pH}$ 7.0. CAT activity was measured by using a UV-Visible spectrophotometer (Shimadzu UV 1800, Torrance, CA, USA) at $240 \mathrm{~nm}$. CAT activity was expressed as U/mg protein.

\subsection{Measurement of SOD Activity in Colon Tissues}

The hyperactivity of SOD was assessed by quantifying its ability to restrain the photochemical reduction of nitro blue tetrazolium (NBT). Superoxide dismutase activity was measured in colonic tissues following the procedures given in [23] with small modifications. The photochemical diminution of riboflavin produces $\mathrm{O}_{2}$ - that deoxidizes the NBT to generate formazan salt, which is measured at an optical density of $560 \mathrm{~nm}$. The conversion of superoxide radical $\left(\mathrm{O}_{2}-\right)$ to peroxide inhibits the reduction of NBT. In a dark room, $20 \mu \mathrm{L}$ of supernatant, $0.5 \mathrm{~mL}$ of $100 \mathrm{mM}$ PBS, $0.2 \mathrm{~mL}$ of $200 \mathrm{nM}$ EDTA, and $0.1 \mathrm{~mL}$ of $15 \mathrm{mM}$ L-methionine, $200 \mu \mathrm{L}$ NBT, $250 \mu \mathrm{L}$ riboflavin were added and this sample was exposed to a fluorescent lamp ( $15 \mathrm{~W}$ ) for $15 \mathrm{~min}$. The SOD activity was measured by using a UV-visible spectrophotometer (Shimadzu UV 1800) at $560 \mathrm{~nm}$. SOD activity was expressed as $\mathrm{U} / \mathrm{mg}$ protein.

\subsection{Measurement of GSH Activity in Colon Tissues}

The reduced GSH concentration was measured in colon tissues [24]. $500 \mu \mathrm{L}$ tissue homogenate was added to $400 \mu \mathrm{L}$ ice-cold $\mathrm{H}_{2} \mathrm{O}$ and $100 \mu \mathrm{L}$ of $60 \%$ trichloroacetic acid. All test tubes were centrifuged at $4000 \mathrm{rpm}$ at $4{ }^{\circ} \mathrm{C}$ for $15 \mathrm{~min}$. The optical density of the supernatant was observed by using a UV-Visible spectrophotometer at $412 \mathrm{~nm}$. For quantitative assessment of GSH (10-100) in nmoles/mg protein, a standardized graph was prepared.

\subsection{Measurement of LPO Activity in Colon Tissues}

Malondialdehyde (MDA) production was detected as TBARS and evaluated using a previously reported method [25]. In brief, $200 \mu \mathrm{L}$ of supernatant was added to $200 \mu \mathrm{L}$ of $15 \%$ trichloroacetic acid; this reaction solution was kept in an ice bath for $10 \mathrm{~min}$ and centrifuged at $4000 \mathrm{rpm}$ for $10 \mathrm{~min}$. $200 \mu \mathrm{L}$ of supernatant was mixed in $200 \mu \mathrm{L}$ of thiobarbituric acid. This reaction solution was kept in a boiling water bath for $5 \mathrm{~min}$ and instantly kept in an ice bath for $5 \mathrm{~min}$. The optical density of the supernatant was observed by using a UV-Visible spectrophotometer at $532 \mathrm{~nm}$. The amount of MDA was shown as nmoles of MDA/mg of protein. 


\subsection{Measurement of MPO Activity in Colon Tissues}

Myeloperoxidase hyperactivity was estimated in colonic tissues [26]. In brief, the supernatant was added to a solution containing $0.5 \%$ CTAB dissolved in $50 \mathrm{mM} \mathrm{PBS}$ (pH 6.5) further, incubated for $10 \mathrm{~s}$ in a freezing bath. The supernatant was thawed twice and then centrifuged at $5000 \mathrm{rpm}$ for $10 \mathrm{~min} .0 .2 \mathrm{~mL}$ of the supernatant was added to $2.8 \mathrm{~mL}$ of $50 \mathrm{mM}$ PBS containing o-dianisidine dihydrochloride and $\mathrm{H}_{2} \mathrm{O}_{2}(0.005 \%)$, and the color developed was measured at $460 \mathrm{~nm}$ by using a UV-Visible spectrophotometer. The myeloperoxidase hyperactivity was calculated according to the following formula:

$$
\text { MPO activity }(\mathrm{mU} / \mathrm{mg})=1000 \times[\mathrm{X} / \text { weight of the colon tissue taken }(\mathrm{mg})]
$$

where $X=10 \times$ difference in absorption per minute/volume of tissue homogenate taken in the final reaction.

\subsection{Determination of Aberrant Crypt Foci (ACF)}

The ACF count was measured using a previously reported technique [27]. The intact colon was excised longitudinally and washed thoroughly in a saline solution prior to fixation process. Then the colon tissue was fixed in $5 \%$ buffered formaldehyde. To detect the ACF, the colon was stained with $0.22 \%$ methylene blue for 3-4 min. Mucosal ACF was enumerated by using a light microscope $(40 \times)$. The aberrant crypts were spotted from normal crypts by its enlarged size, the clogged and deeply stained perceptive zones.

\subsection{Mast Cell Staining on Colon of Experimental Animals}

Histopathological examination of mast cells was examined in colon tissues [28]. The $5 \mu \mathrm{m}$ thick colon tissues were de-waxed in xylene and re-hydrated by decreasing $\mathrm{EtOH}$ concentration in d. $\mathrm{H}_{2} \mathrm{O}$ (distilled water). These sections were then stained with toluidine blue for $3 \mathrm{~min}$, washed with double d. $\mathrm{H}_{2} \mathrm{O}$, dehydrated in enhancing concentrations of alcohol from beginning to end series, and then fixed with dibutyl phthalate in xylene (DPX). A high-power objective field $(40 \times)$ was selected for counting mast cells in 10 alternative fields/slides.

\subsection{Statistical Analysis}

All data were presented as mean \pm standard deviation. Statistical analysis of the data was performed by one-way analysis of variance (ANOVA) followed by Tukey's multiple range tests for post-hoc analysis using the Sigmastat Version 3.5 software (Systat Software Inc., San Jose, CA, USA). The significance level was set at $p<0.05$.

\section{Results}

\subsection{Effect of Sal B on AA-Induced Colitis}

By comparing the colitis group to the untreated control group, physiological investigations revealed significant changes in colon length, body weight, fecal blood, and general health. Compared with group 1 (Control), the \% of body weight drastically decreased in the AA-induced colitis group 2 mice. The minimal disease activity state was elevated in the AA-induced colitis group. However, the supplementation of Sal B ameliorated the body weight, and statistically, major differences were obtained starting on day 5 . The length of the colon is considered being inversely proportional to the severity of AA-induced experimental colitis. The consequential shrinking of the colon length (Figure 3A) and macroscopic score (Figure 3B) was observed in the AA-induced mice, along with marked infiltration of inflammatory cells, extensive eradication of mucosal layer, loss of crypts, and submucosal edema, and these morphological changes suppressed following treatment with $40 \mu \mathrm{g} / \mathrm{kg}$ of Sal B (Figure 3A-C). 
(A)

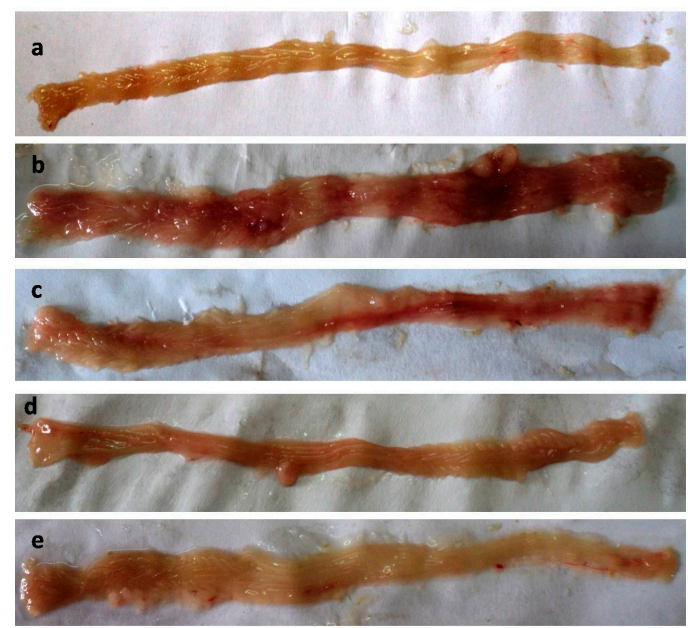

(B)

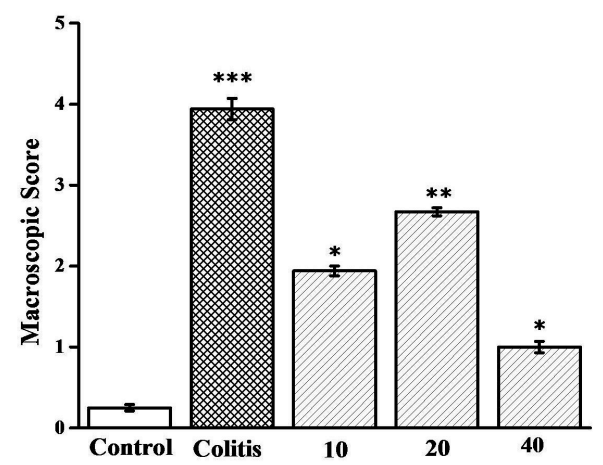

(C)

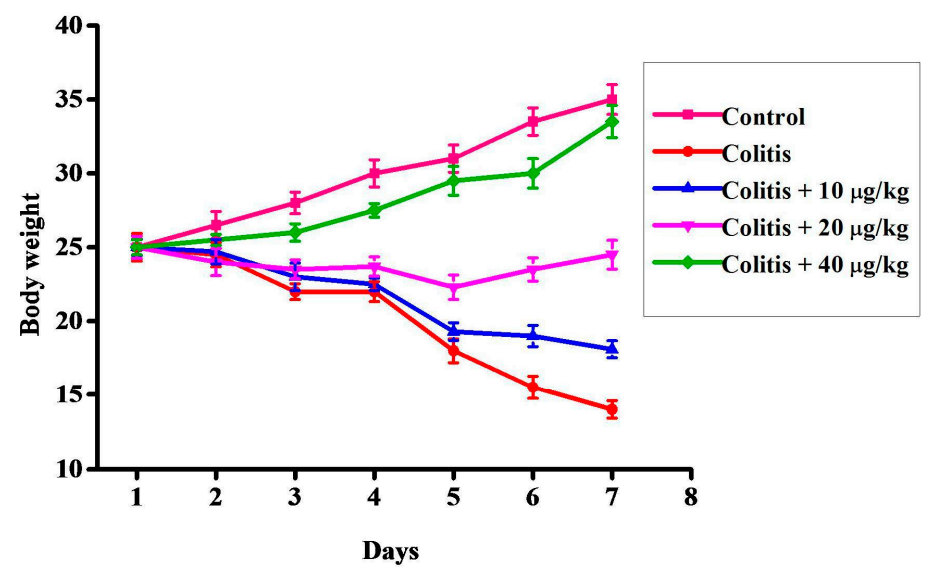

Figure 3. Therapeutic effect of Sal B on the body weight changes of mice with colitis. (A) The mice were given only saline (a. control group), saline containing 5\% AA (b. colitis group 2), AA + $10 \mu \mathrm{g} / \mathrm{kg}$ Sal B (c. group 3), AA + $20 \mu \mathrm{g} / \mathrm{kg} \mathrm{Sal} \mathrm{B}$ (d. group 4), AA $+40 \mu \mathrm{g} / \mathrm{kg}$ Sal B (e. group 5), (A) Representative morphological changes of colon tissues. In each group, colon samples were collected from mice. Interestingly, Sal B decreased the degree of ulcer index and colon shortening in a dose-dependent manner. (B) Macroscopic assessment of colons from AA-induced experimental colitis. (C) Effect of daily treatment with Sal B changes in body weight in experimental colitis. AA-acetic acid; Sal B-Salvianolic acid B, ${ }^{*} p<0.05$, ${ }^{* *} p<0.01,{ }^{* * *} p<0.001$ as compared with control.

\subsection{Sal B Decreases Microscopic Colon Damage in AA-Induced Experimental Colitis}

The histopathological character of the colonic tissue was evaluated by hematoxylin and eosin (H\&E) staining. Typical histopathological results are shown in Figure 4. The control mice showed clear colonic mucosa without edema, erosion, or ulceration (Figure 4A). The anatomy of the colon wall in the colitis model mice (group 2) had a characteristic morphology with crypts, edema, thickness and erosion of the colonic mucosa, numerous goblet cells, and a minimal number of lamina propria mononuclear cells. Compared with group 1 (Control), microscopic histopathological scores were considerably elevated in mice from the AA-induced colitis (group 2) (Figure 4B). Mild histopathological changes occurred in group 3 and group 4 (Figure 4C,D). After the treatment of Sal B a considerable decrease in the histopathological count, intact colonic mucosa structure, milder congestion and edema and less inflammatory cell infiltration were observed in group 5 mice as compared with the control group 1 (Figure 4E). 

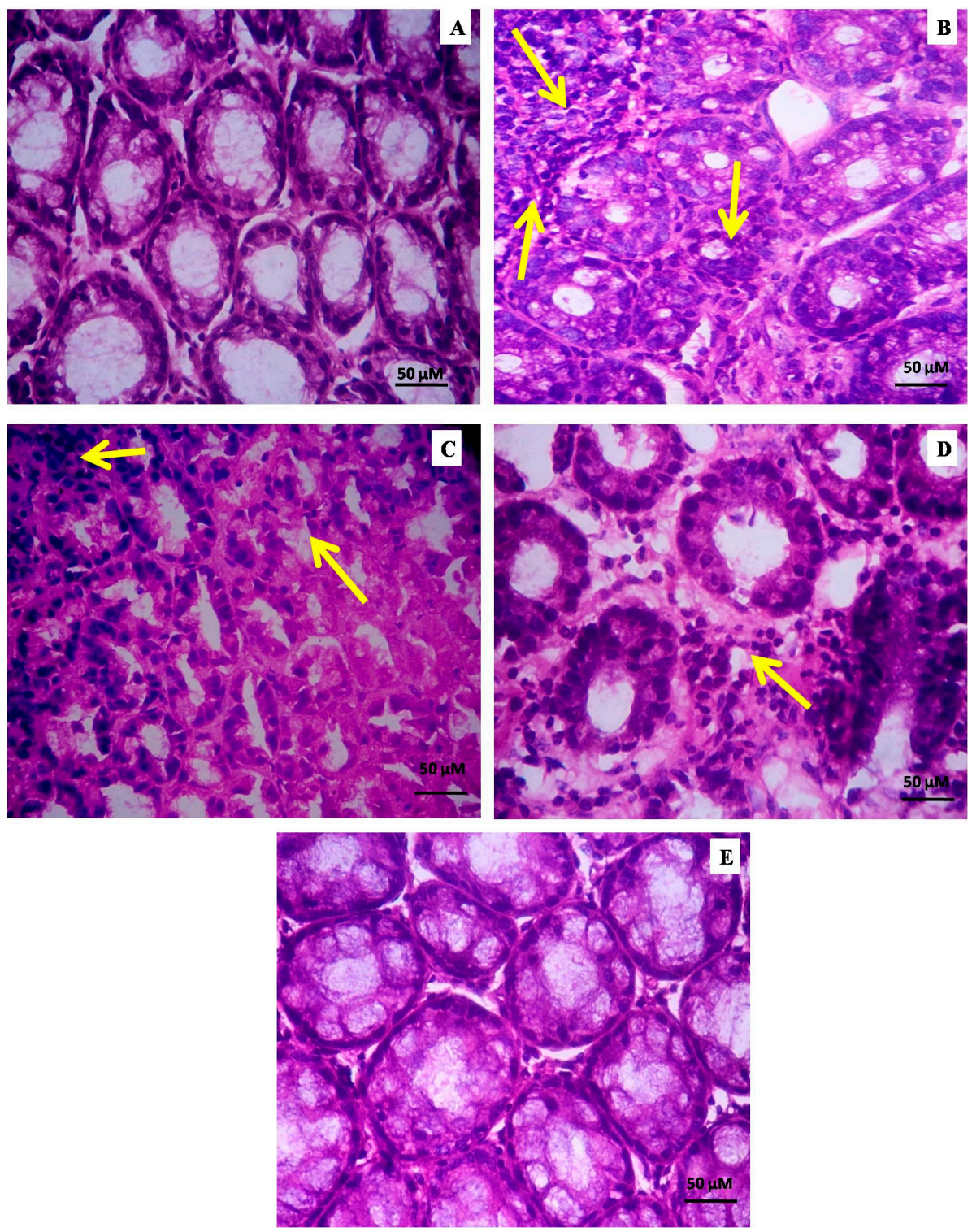

Figure 4. Histopathological changes in colons from mice stained with H\&E. (A) Control mice receiving saline only, showing normal histological structures. (B) 5\% AA-induced colon with ulcerative colitis, Group 2 showed marked neutrophil infiltration, thickening of colonic mucosa, severe destruction of epithelial structure with ulceration and infiltration of inflammatory cells compared with control (group 1). (C,D) Mice were administered with AA, Sal B (10, $20 \mu \mathrm{g} / \mathrm{kg}$ respectively), Group 3 and 4 showed mild histological colonic mucosa changes (C,D). Group 5 showed the intact colonic mucosa structure, milder congestion and edema and less inflammatory cell infiltration (E).

\subsection{Effect of Sal B on CAT Activity in Colon Tissues}

Catalase acts as an enzyme essential for the detoxification of $\mathrm{H}_{2} \mathrm{O}_{2}$ during the reaction mediated by SOD. In the current study, the catalase activity was drastically decreased in AA-induced mice colonic tissue (group 2) (Figure 5A). Catalase frames the energetic cellular defense that involved carcinogen deactivation of ecosystem factors. In this catalase, enzymatic activity was increased in the treatment of Sal B in the experimental animals. Mice treated with 10, $20 \mu \mathrm{g} / \mathrm{kg}$ of Sal B showed a considerable enhancement of CAT activity when compared with colitis group 2 . Treatment with Sal B $(40 \mu \mathrm{g} / \mathrm{kg})$ significantly increased the colonic tissue CAT activity in group 5 when compared with colitis group 2 (Table 1). 

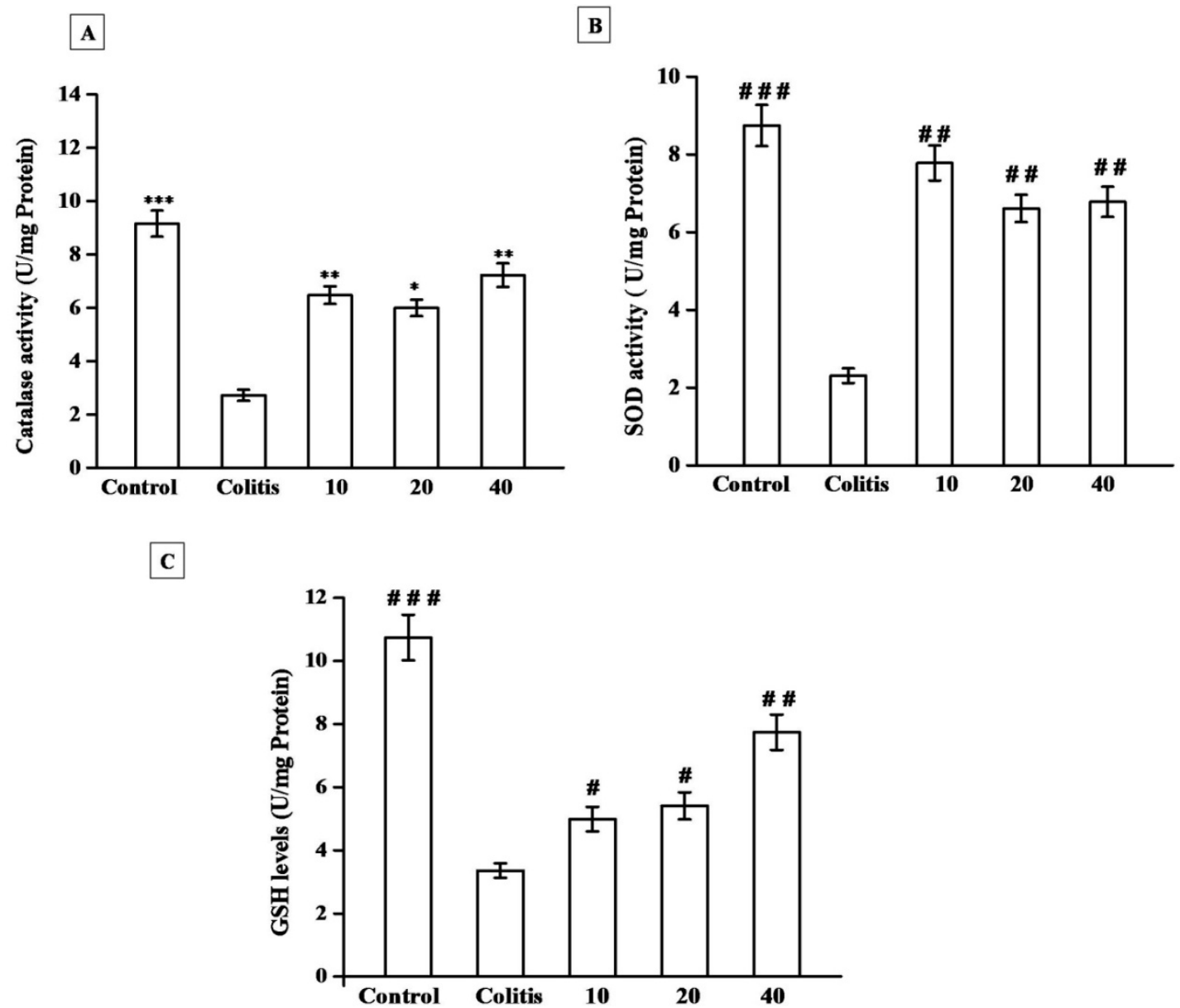

Figure 5. Effect of Sal B on enzymatic activities in mice colon tissue with AA-induced experimental colitis $(n=6)$. (A) Catalase activity, ${ }^{*} p<0.05,{ }^{* *} p<0.01,{ }^{* * *} p<0.001$ as compared with control, (B) Superoxide dismutase activity and (C) GSH level. The data are represented as mean \pm SD and evaluated using one-way ANOVA, followed by Tukey's multiple range tests for post hoc analysis. ${ }^{\#} p<0.05,{ }^{\#} p<0.01,{ }^{\# \# \#} p<0.001$ as compared with control.

Table 1. Effect of Sal B on colon catalase, SOD, and GSH concentration.

\begin{tabular}{cccc}
\hline Parameters/Groups & $\begin{array}{c}\text { Colon Catalase Activity ( } \boldsymbol{\mu m o l} \\
\mathbf{H}_{\mathbf{2}} \mathbf{O}_{\mathbf{2}} / \mathbf{m i n} / \mathbf{m g} \text { Protein) }\end{array}$ & $\begin{array}{c}\text { Colon SOD Activity (U/mg } \\
\text { Protein) }\end{array}$ & $\begin{array}{c}\text { Colon GSH Activity } \\
\text { (nmol/mg Protein) }\end{array}$ \\
\hline Control (Saline) & $9.15 \pm 0.489$ & $8.74 \pm 0.53$ & $10.74 \pm 0.72$ \\
Colitis (AA) & $2.72 \pm 0.213$ & $2.31 \pm 0.19$ & $3.36 \pm 0.23$ \\
Colitis + 10 $\mu \mathrm{g}$ Sal B & $6.47 \pm 0.331$ & $7.78 \pm 0.45$ & $4.99 \pm 0.39$ \\
Colitis + 20 $\mu \mathrm{g}$ Sal B & $5.99 \pm 0.361$ & $6.61 \pm 0.35$ & $5.41 \pm 0.43$ \\
Colitis + 40 $\mu \mathrm{g}$ Sal B & $7.22 \pm 0.443$ & $6.78 \pm 0.39$ & $7.74 \pm 0.56$ \\
\hline
\end{tabular}

Data are expressed as mean $\pm \mathrm{SEM}, n=6$. Statistical analysis was performed using One-Way ANOVA followed by Tukey-Kramer multiple comparisons test $(p<0.05)$.

\subsection{Effect of Sal B on SOD Activity in Colon Tissues}

The reduced SOD activity in the colon with inflammation could lead to a decrease in abdominal immunity versus oxidative stress, which is directly linked to colon injury in ulcerative colitis. The control group 1 mice showed significantly increased colonic SOD activity while comparing to the AA-induced colitis group 2 mice. Experimental animals treated with 10, $20 \mu \mathrm{g} / \mathrm{kg}$ of Sal B showed a significant increase of SOD activity when compared with colitis group 2. Table 1 represented supplementation of Sal B $(40 \mu \mathrm{g} / \mathrm{kg})$ ameliorates the colonic tissue SOD activity when compared with colitis group 2 mice (Figure 5B). 


\subsection{Effect of Sal B on GSH Activity in Colon Tissues}

Glutathione is a tripeptide thiol molecule and is a reducing agent, being the foremost low molecular weight thiol found in mammals. The effectiveness of Sal B on AA-induced mice in the GSH content was found to significantly improved. In our study, Sal B has considerably reduced the level of GSH content in group 2 when compared with group 1. When compared to control mice, AA treatment resulted in a significant decrease in colonic GSH levels. Experimental animals treated with 10, $20 \mu \mathrm{g} / \mathrm{kg}$ of Sal B showed a moderate increase of GSH activity when compared with colitis group 2. GSH levels were considerably lower in group 5 mice following supplementation with $40 \mu \mathrm{g} / \mathrm{kg}$ of Sal B (Figure 5C) compared to group 2 mice (Table 1).

\subsection{Effect of Sal B on MDA Levels in Colon Tissues}

Sal B inhibits lipid peroxidation caused by AA-induction in mice. Compared with group 1, the AA-induced colitis group 2 mice, and leads to a significant elevation of MDA levels. MDA is a known biomarker that plays a key role in tissue damage. AA-induced colitis group 2 shows an elevated level of MDA when compared with untreated control group 1. Mice treated with 10, $20 \mu \mathrm{g} / \mathrm{kg}$ of Sal B indicated a mild decline of MDA level when compared with colitis group 2. When compared to AA-induced experimental colitis mice, supplementation of Sal B with higher dosages $(40 \mu \mathrm{g} / \mathrm{kg})$ significantly decreases MDA levels in group 5 (Figure 6A).
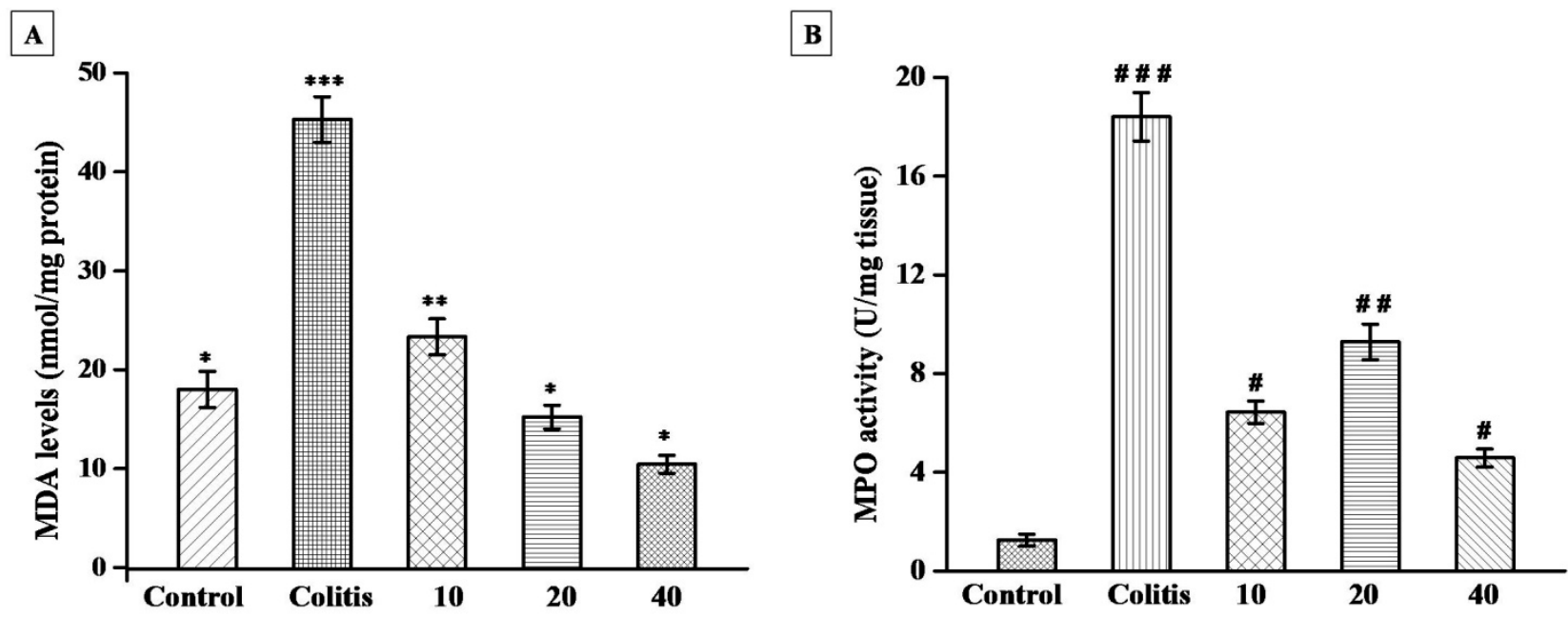

Figure 6. Effect of Sal B on LPO and MPO activity in mice's colon tissue with AA-induced experimental colitis $(n=6)$. (A) Effect of Sal B on lipid peroxidation ${ }^{*} p<0.05,{ }^{* *} p<0.01,{ }^{* * *} p<0.001$ as compared with control, (B) Effect of Sal B on MPO activity. The data are represented as mean \pm SD and evaluated using one-way ANOVA, followed by Tukey's multiple range tests for post hoc analysis. ${ }^{\#} p<0.05,{ }^{\# \#} p<0.01,{ }^{\# \# \#} p<0.001$ as compared with control.

\subsection{Effect of Sal B on Myeloperoxidase Activity in Colon Tissues}

The inflammatory state of the colonic mucosa causes an increase in MPO enzyme expression, which leads to increased oxidative stress. In this study, colonic myeloperoxidase activity was considerably elevated in the AA-induced colitis mice when compared to group 1. Mice treated with $10,20 \mu \mathrm{g} / \mathrm{kg}$ of Sal B showed a moderate decrease of myeloperoxidase activity when compared with colitis group 2 . In addition, Table 2 indicates mice treated with Sal B with higher doses $(40 \mu \mathrm{g} / \mathrm{kg})$ in group 5 showed significantly decreased MPO activity (Figure 6B). 
Table 2. Effect of Sal B on colon MDA levels, and MPO activity.

\begin{tabular}{ccc}
\hline Parameters/Groups & $\begin{array}{c}\text { Colon MDA Levels } \\
\text { (nmol/mg Protein) }\end{array}$ & $\begin{array}{c}\text { Colon MPO Activity (U/mg } \\
\text { Tissue) }\end{array}$ \\
\hline Control & $18.02 \pm 1.87$ & $1.25 \pm 0.14$ \\
\hline Colitis & $45.29 \pm 2.34$ & $18.42 \pm 0.98$ \\
\hline Colitis+ $10 \mu \mathrm{g}$ Sal B & $23.34 \pm 1.83$ & $6.43 \pm 0.45$ \\
\hline Colitis+ 20 $\mu \mathrm{g}$ Sal B & $15.21 \pm 1.24$ & $9.28 \pm 0.72$ \\
\hline Colitis+ $40 \mu \mathrm{g}$ Sal B & $10.44 \pm 0.91$ & $4.58 \pm 0.36$ \\
\hline
\end{tabular}

Data are expressed as mean \pm SEM, $n=6$. Statistical analysis was performed using One-Way ANOVA followed by Tukey-Kramer multiple comparisons test $(p<0.05)$. Significantly different vs. normal control $(p \leq 0.05)$.

\subsection{Methylene Blue Staining of Aberrant Crypt Foci (ACF) of Experimental Mice}

The untreated colonic mucosa of colonic tissue-stained crypts was investigated with methylene blue staining to detect aberrant crypts. Their enormous size, oval form, and thick epithelial lining along with a more massively colossal per crystal zone characterized from normal crypts AA-induced colonic crypts, as shown by their gloomy staining (Figure 7A-E). In the AA-induced mice, group 2 showed a high number of ACF compared with the control group (normal crypt) (Figure 7A,B).
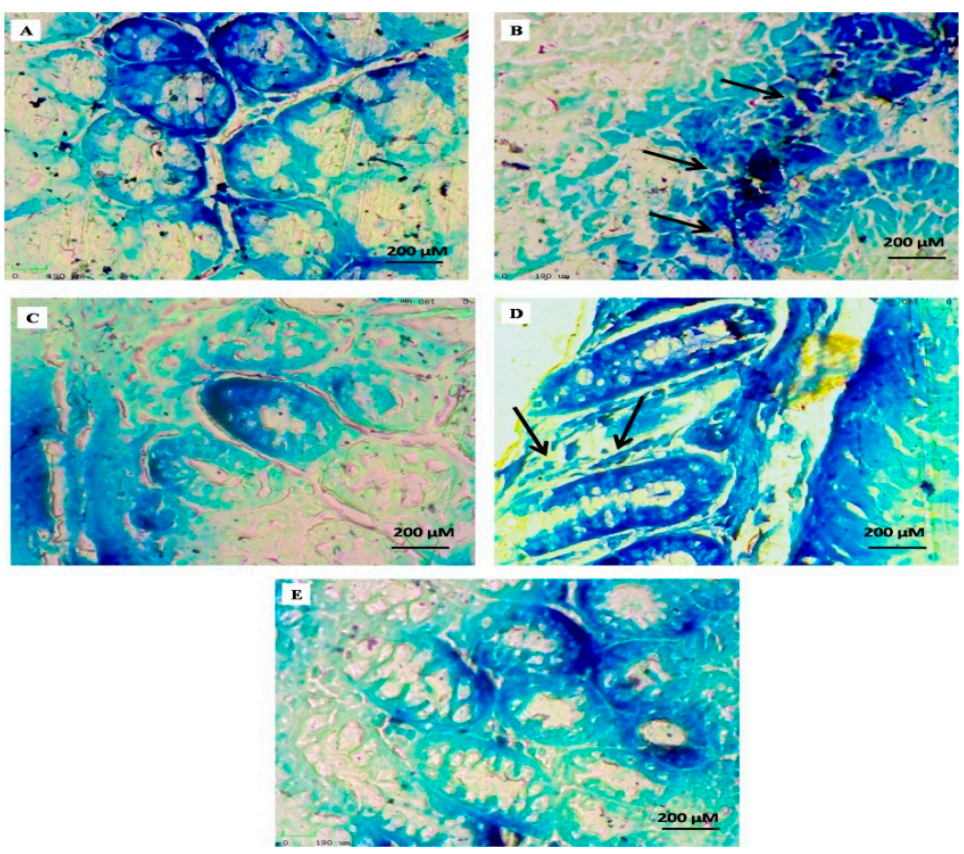

Figure 7. Morphological observations of aberrant crypt foci. (A) The control group showed typical crypt appearance, (B) AA-induced colitis group showed an increased number of crypts per foci, (C,D) Group 3 and 4 showed only a few crypts, (E) Group 5 showed normal crypt-like control.

There are moderate changes in colon tissues treated with $10,20 \mu \mathrm{g} / \mathrm{kg}$ of Sal B were shown in groups 3 and 4 . In our study confirmed, $75 \%$ reduction of ACF prevalence in mice administrated with $40 \mu \mathrm{g} / \mathrm{kg}$ of Sal B (group 5), while there was no ACF prevalence in control mice (group 1) as clearly presented in Figure 7E.

\subsection{Mast Cell Count of Control and Experimental Mice}

The accumulation of many inflammatory cells, mast cells, and eosinophils in the gut mucosa is a well-known morphologic feature of ulcerative colitis. The crypt epithelium was depleted from goblet cells and also observed the ulcer crypt. In addition, inflammatory cell infiltration in lamina propria such as lymphocytes and plasma cells was observed 
(Figure 8A-E). A degenerated colonic mucous layer and asymmetrical epithelial glands were observed in group 2 mice, corresponding to a high number of mast cells compared to group 1. Treatment of 10,20 $\mu \mathrm{g} / \mathrm{kg}$ of Sal B significantly decreased the amount of mast cells in the colon of groups 3 and 4 . Reduced mast cell incidence was seen in mice supplemented with $40 \mu \mathrm{g} / \mathrm{kg}$ of Sal B (group 5), while in control mice there were no mast cells as clearly shown in Figure 8E.
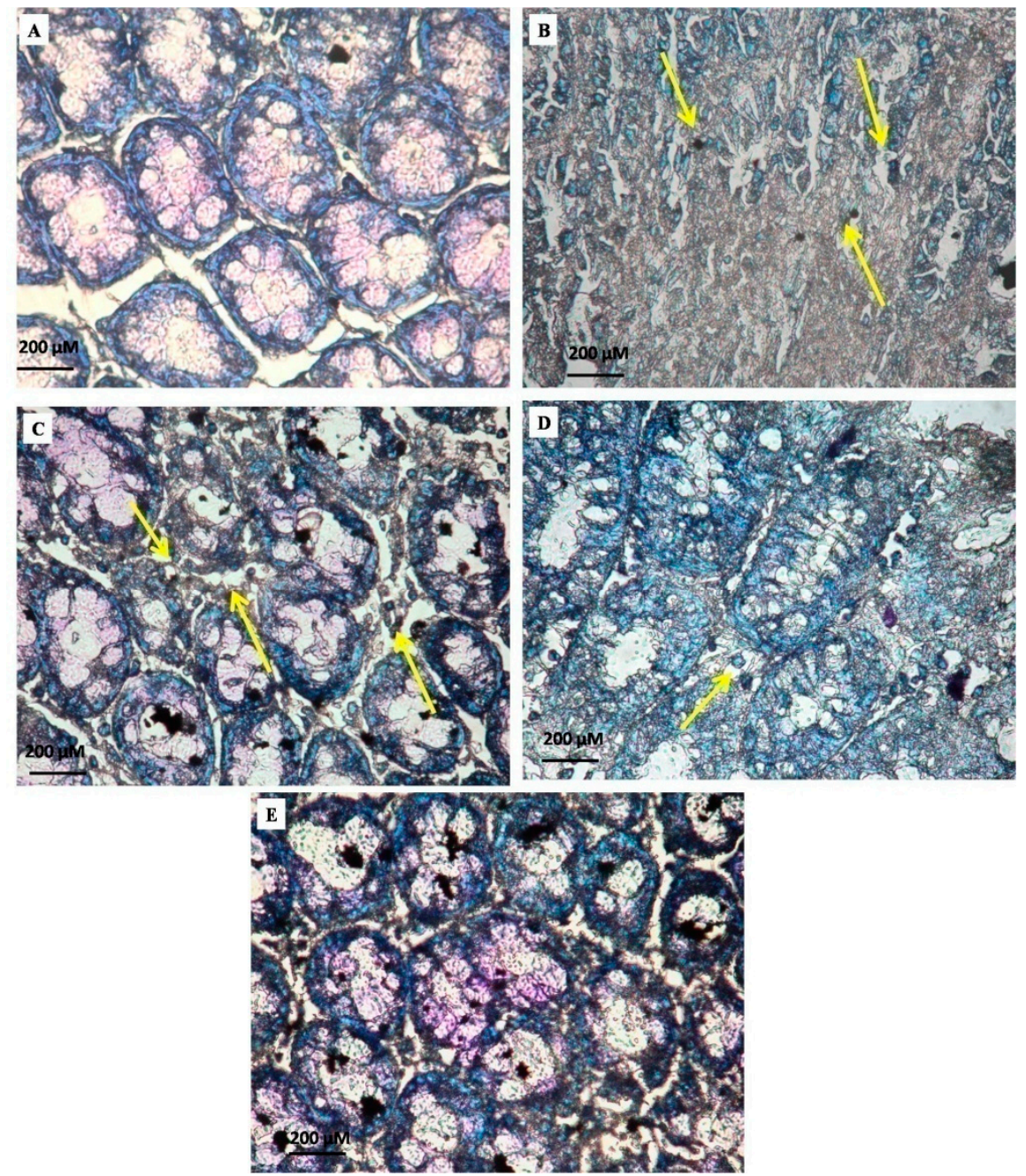

Figure 8. Photomicrographs of mast cell count. (A) The control group showed normal architecture lack of mast cells. (B) Ulcerated colonic crypts showed a considerably increased concentration of mast cells. (C,D) showed a moderate concentration of mast cells. Additionally, $40 \mu \mathrm{g} / \mathrm{kg}$ of Sal B treated Group 5 mice showed a significantly reduced concentration of mast cells (E).

\section{Discussion}

Ulcerative colitis (UC) is a form of inflammatory bowel disease defined as a long chronic inflammatory process, as well as dysbiosis. Diet is an important aspect that influences human health and has a lot of potential in the diagnosis and treatment of UC [29]. This study described that chronic inflammation is connected with an overproduction of unpaired free radical species and has a primary role in numerous pathological conditions such as melanoma, sarcoma, coronary artery diseases, myocardial infarction, obesity, and inflammatory bowel disease [30-32]. Flavonoids have been shown in vivo and in vitro to prevent cells from oxidative stress and to protect the epithelial mucosal layer of the intestines [33]. Antioxidant foods such as blueberries, artichokes, bell peppers, cherries, pecans, squashes, strawberries, red cabbage, raspberry, and tomatoes are recommended as supplementation for individuals with chronic UC and to prevent recurrence [34,35]. The 
current study evaluated the medicinal effects of Sal B treatment in chemically-induced experimental colitis in a mice model that resembles the UC state in human trials. The experimental mice model revealed typical UC indications such as diarrhea, cramps, bloody stools and mucosal ulceration, stimulated increased mucous blood flow and shortened colons $[1,36]$.

Sal B, an antioxidant, was helpful in preventing and treating AA-induced colitis in mice, as well as modifying the degree and severity of colitis [37]. Oral administration of Sal B in AA-induced colitis mice showed that Sal B improved body weight and enhanced stool stability while reducing the rate of bloody stools, and Sal B protected AA-treated mice from mucosa erosion, colon shortening, inflammatory cell infiltration, submucosal edema, loss and disruption of crypt and villi. Significant increases in body weight, microscopic and macroscopic scores, bleeding in the rectum, histopathological modifications, and shearing of epithelial cells were seen depending on the severity of inflammation in ulcerative colitis [38].

The antioxidant system depends on both SOD and GSH are important components. SOD is an antioxidant enzyme that transforms superoxide radicals to $\mathrm{H}_{2} \mathrm{O}_{2}$, which is then converted into molecular oxygen and $\mathrm{H}_{2} \mathrm{O}$ by catalase. $\mathrm{GSH}$ is an intracellular free radical scavenger $[39,40]$. GSH and GR contribute to detoxifying environmental carcinogenic substances including reactive oxygen species and hydroxyl radicals by combining toxins with GSH and ultimately preventing tissues and organs, toward toxicity induced by carcinogens GSH and GR primarily contribute to the detoxification of environmental carcinogens [41-43]. In the current study, SOD and GSH content were reduced in ulcerative colitis caused by acetic acid; however, Sal B therapy was able to reverse the decrease. Sal B showed intrinsic antioxidant properties that could improve intestinal antioxidant status, which is in accordance with previous findings. Oxidative stress is caused by increased oxidant levels and/or a depleted antioxidant system, and it has been related to the development of ulcerative colitis. Lipid peroxidation develops progressively in cellular and subcellular membranes during oxidative stress, causing irreversible damage to cellular function. The lipid peroxidation product MDA was significantly elevated in AA-induced colitis, whereas Sal B administration significantly decreased MDA levels in the colon of AA-induced mice [37]. MPO, as a sign of inflammation, might facilitate oxidative tissue damage, whereas Sal B therapy dramatically reduced MPO activity in AA-treated colonic mice.

Mitochondria maintain cellular energy engendered through oxidative phosphorylation [44]. The small mitochondrial genes are indispensable for the enzyme involved in the cellular biosynthetic and oxidative function. ROS is a major cause of UC. Cellular macromolecules such as proteins, DNA, and lipids are damaged by oxidative stress. ROS are involved in the development of colitis $[45,46]$. Several researchers have suggested that intra-rectal administration of AA-generated reactive oxygen species leads to modifications in oxidative marker levels, including GSH, MDA and MPO [47]. The LPO level is indirectly quantified by the amount of MDA production, which leads to damage to the mitochondrial dysfunction $[47,48]$. However, administration of Sal B decreases the MDA level in experimental colitis. Sal B blocks neutrophil infiltration, increasing the production of cytokines, and oxidative burst into ulcerated tissues. In addition to immune cells, macrophages, antigen-presenting cells and intestinal epithelial cells, cytokines are considered key signals in the gastrointestinal immune system and are directly implicated in the secretion of several cytokines that control the inflammatory response in ulcerative colitis [49-51].

Most of the ACF was identified by investigating the sequential early development of erosions in mice colon following acetic acid induction. ACF was characterized by mildly enlarged or small crypts and collections of abnormally appearing colonic crypts that degrade from the surrounding epithelium [52-54]. The crypt is concise, as well as similar to a condensed luminal opening. ACF measures resemblance among the tumors regarding the apparent morphology of the colon, pathologic classification, and high crypt multiplicity. The present study results correlated with previous reports, AA-induced mice showed an 
elevated number of colonic crypts. Also, the administration of Sal B significantly reduces the number of crypt formations shown in Figure 8.

Mast cells regulate important gastrointestinal activities including blood flow, epithelial cell functions, secretary functions and endothelial permeability, mucus secretion, upregulate membrane expression, GI tract motility, defensins release, neuroimmune interaction, and cancer development $[55,56]$. Mast cells, as well as tumor cell interactions in their biophysical environment, are essential for cell proliferation and rate of survival. Mast cells are well-known as important effector cells in the gut immune system [57]. Mast cells can be triggered by a range of stimuli, causing them to degranulate and generate a number of biologically active mediators of inflammation, tryptase, hexosaminidase, chemokines, and cytokines, among others [58,59]. An elevation in mast cell levels in the gastrointestinal tract can lead to mast cell-mediated epithelial tissue injury because many mast cell mediators are pro-inflammatory and can trigger gastrointestinal immunological disorders $[55,56,60]$. This study mainly focused on the induction of AA that increased inflammatory mast cells creating a microenvironment that leads to a progression of colitis.

The role of systemic inflammation in the genesis and recurrence of cancer is a key research topic in tumor cells. At various stages of UC progression and colitis-associated tumorigenesis, ROS and oxidative stress are key components in the initiation, development, and progression. Ulcerative colitis was initiated by an increase in MDA and MPO levels, as well as mitochondrial dysfunction (Figure 9). Within the intestinal mucosa, activated neutrophils can create ROS, increasing oxidative stress and playing a role in the formation of UC [61]. Excessive generation of ROS in mucosal cells during experimental colitis can trigger a series of inflammatory mechanisms that damage gastrointestinal epithelial cells, directly or indirectly, disrupting the intestinal mucosal barrier stability [62].

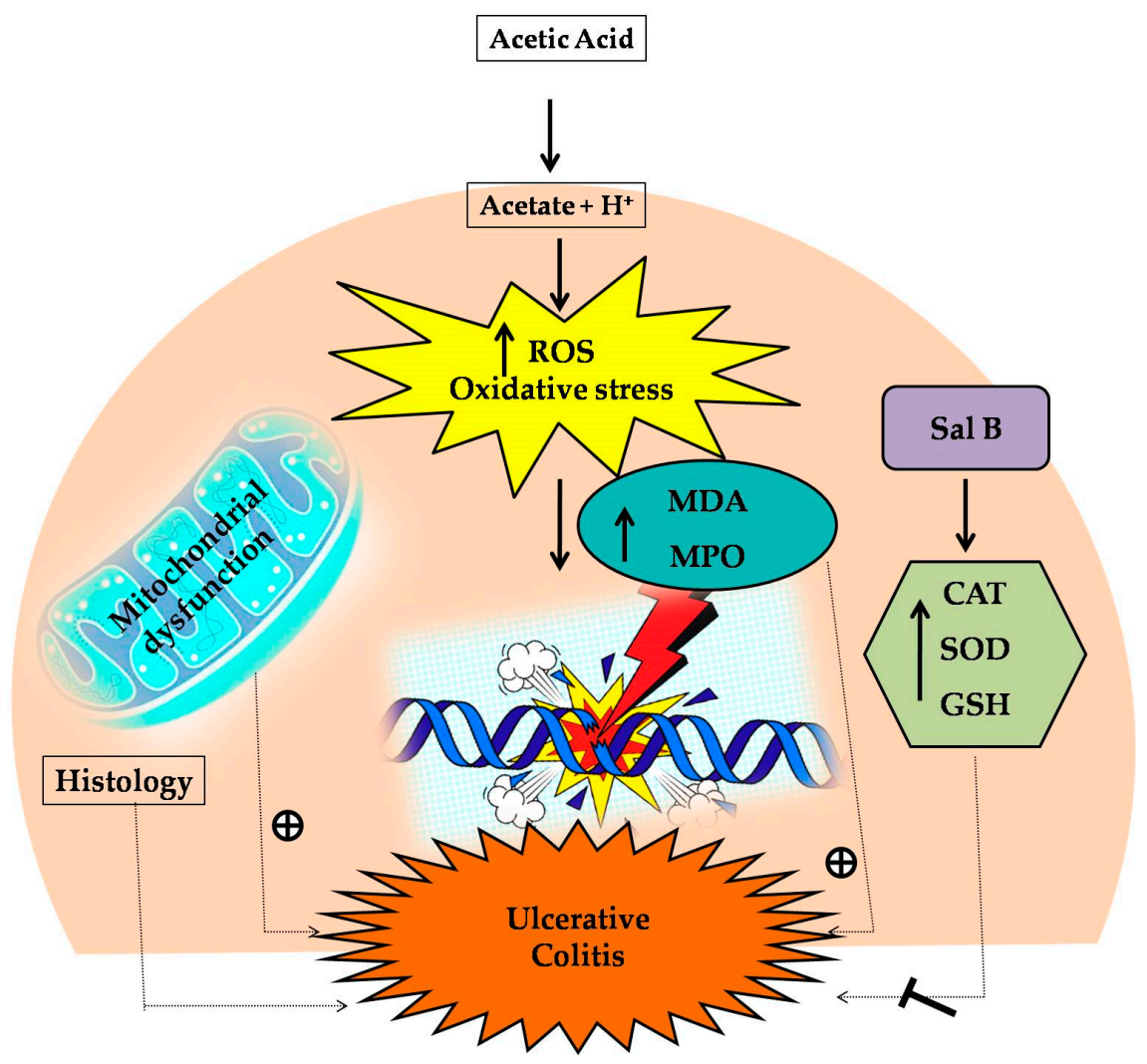

Figure 9. The mechanism of action of Sal B in AA-induced ulcerative colitis.

\section{Conclusions}

The major finding of this study is the protective effectiveness of Sal B on local as well as systemic pathological changes induced by acetic acid in colon tissue. The biolog- 
ical effects of Sal B effectively decrease oxidative stress, elevated antioxidant properties. Symptoms include body weight loss, colon tissue shortening, diarrhea, and increased colon weight/length ratio, and a reduced disease activity index (DAI) score. Damage to colon tissues was reversed, and biochemical indices such as SOD, CAT, and GSH were improved. Therapeutic approaches that stabilized MPO and MDA levels suggest that Sal B may reduce the risk of chronic conditions. Finally, Sal B considerably inhibited the incidence of $\mathrm{ACF}$, the alternative effect of preneoplastic ulceration and decline of mast cell count in the AA-induced experimental colitis model used. Our findings suggest that Sal B might have good prospects for future development in the clinical treatment for ulcerative colitis and cancer prevention.

Author Contributions: Conceptualization, M.G. and M.V., Data curation, M.P., M.A.A., Formal analysis, M.N.A., Funding acquisition, S.A. (Sami AlYahya), S.A. (Saad Alghamdi), A.M.B., M.A., Supervision, M.V., Writing—original draft, M.G., M.V., Writing—review \& editing, M.T., G.R., E.G. and P.A. All authors have read and agreed to the published version of the manuscript.

Funding: The authors like to thank Taif University, Taif, Saudi Arabia, for their support (Taif University Researchers Supporting Project number: TURSP-2020/80), Taif University, Taif, Saudi Arabia.

Institutional Review Board Statement: The study was conducted according to the guidelines of the Declaration of Helsinki and approved by the Animal Care and Use Committee of Periyar University and Laboratory Animal-Guideline for ethical review of animal welfare (1085/ac/07/CPCSEA/PUIAEC/March-2014/06).

Informed Consent Statement: Not applicable.

Data Availability Statement: Not applicable.

Conflicts of Interest: The authors declare that they have no competing interests.

Ethics Approval: All care, maintenance and experimental protocols were performed in accordance with the Animal Care and Use Committee of Periyar University (Tamil Nadu, India).

\section{References}

1. Gryaznova, M.V.; Solodskikh, S.A.; Panevina, A.V.; Syromyatnikov, M.Y.; Popov, E.S.; Popov, V.N. Study of microbiome changes in patients with ulcerative colitis in the Central European part of Russia. Heliyon 2021, 7, e06432. [CrossRef] [PubMed]

2. Amirshahrokhi, K. Febuxostat attenuates ulcerative colitis by the inhibition of NF- $\mathrm{KB}$, proinflammatory cytokines, and oxidative stress in mice. Int. Immunopharmacol. 2019, 76, 105884. [CrossRef]

3. Tripathi, K.; Feuerstein, J.D. New developments in ulcerative colitis: Latest evidence on management, treatment, and maintenance. Drugs Context 2019, 8, 212572. [CrossRef]

4. Elflein, J. Projected prevalence of inflammatory bowel disease (IBD) in select countries in North America and Europe in 2010, 2020, and 2030. Statista 2021. Available online: https:/ / www.statista.com/statistics/1206510/projected-ibd-population-in-selectcountries-north-america-europe/ (accessed on 5 September 2021).

5. Neubauer, K.; Kempinski, R.; Matusiewicz, M.; Bednarz-Misa, I.; Krzystek-Korpacka, M. Nonenzymatic serum antioxidant capacity in IBD and its association with the severity of bowel inflammation and corticosteroids treatment. Medicina 2019, 55, 88. [CrossRef] [PubMed]

6. Zhu, Y.; Yang, S.; Zhao, N.; Liu, C.; Zhang, F.; Guo, Y.; Liu, H. CXCL8 chemokine in ulcerative colitis. Biomed. Pharmacother. 2021, 138, 111427. [CrossRef]

7. Shi, W.; Zou, R.; Yang, M.; Mai, L.; Ren, J.; Wen, J.; Liu, Z.; Lai, R. Analysis of genes involved in ulcerative colitis activity and tumorigenesis through systematic mining of gene co-expression networks. Front. Physiol. 2019, 10, 662. [CrossRef]

8. Tian, M.; Ma, P.; Zhang, Y.; Mi, Y.; Fan, D. Ginsenoside Rk3 alleviated DSS-induced ulcerative colitis by protecting colon barrier and inhibiting NLRP3 inflammasome pathway. Int. Immunopharmacol. 2020, 85, 106645. [CrossRef]

9. $\quad$ El-Naggar, M.E.; Hussein, J.; El-sayed, S.M.; Youssif, A.A.; El Bana, M.; Latif, Y.A.; Medhat, D. Protective effect of the function yogurt based on Malva parviflora leaves extract nanoemulsion on acetic acid-induced ulcerative colitis in rats. J. Mat. Res. Technol. 2020, 9, 14500-14508. [CrossRef]

10. George, L.A.; Cross, R.K. Treatment of ulcerative colitis with steroids (in whom, how long, what Dose, what form). Gastroenterol. Clin. N. Am. 2020, 49, 705-716. [CrossRef]

11. Liu, K.; Li, G.; Guo, W.; Zhang, J. The protective effect and mechanism of pedunculoside on DSS (dextran sulfate sodium) induced ulcerative colitis in mice. Int. Immunopharmacol. 2020, 88, 107017. [CrossRef] [PubMed]

12. Ren, J.; Fu, L.; Nile, S.H.; Zhang, J.; Kai, G. Salvia miltiorrhiza in treating cardiovascular diseases: A review on its pharmacological and clinical applications. Front Pharmacol. 2019, 10, 753. [CrossRef] [PubMed] 
13. Lin, J.; Lin, R.; Li, S.; Wu, H.; Ding, J.; Xiang, G.; Li, S.; Wang, Y.; Lin, D.; Gao, W.; et al. Salvianolic acid B promotes the survival of random-pattern skin flaps in rats by inducing autophagy. Front. Pharmacol. 2018, 9, 1178. [CrossRef]

14. Fan, Y.; Luo, Q.; Wei, J.; Lin, R.; Lin, L.; Li, Y.; Chen, Z.; Lin, W.; Chen, Q. Mechanism of salvianolic acid B neuroprotection against ischemia/reperfusion induced cerebral injury. Brain Res. 2018, 1679, 125-133. [CrossRef]

15. Qiao, J.; Liu, A.; Liu, J.; Guan, D.; Chen, T. Salvianolic acid B (Sal B) alleviates the decreased activity induced by prednisolone acetate on osteoblasts by up-regulation of bone formation and differentiation genes. Food Funct. 2019, 10, 6184-6192. [CrossRef]

16. Lin, M.; Zhai, X.; Wang, G.; Tian, X.; Gao, D.; Shi, L.; Wu, H.; Fan, Q.; Peng, J.; Liu, K.; et al. Salvianolic acid B protects against acetaminophen hepatotoxicity by inducing Nrf2 and phase II detoxification gene expression via activation of the PI3K and PKC signaling pathways. J. Pharmacol, Sci. 2015, 127, 203-210. [CrossRef]

17. Neurath, M.F.; Fuss, I.; Pasparakis, M.; Alexopoulou, L.; Haralambous, S.; Meyer zumBüschenfelde, K.H.; Kollias, G. Predominant pathogenic role of tumor necrosis factor in experimental colitis in mice. Eur. J. Immunol. 1997, 27, 1743-1750. [CrossRef] [PubMed]

18. Morris, G.P.; Beck, P.L.; Herridge, M.S.; Depew, W.T.; Szewczuk, M.R.; Wallace, J.L. Hapten-induced model of chronic inflammation and ulceration in the rat colon. Gastroenterology 1989, 96, 795-803. [CrossRef]

19. Niu, X.; Fan, T.; Li, W.; Huang, H.; Zhang, Y.; Xing, W. Protective effect of sanguinarine against acetic acid-induced ulcerative colitis in mice. Toxicol. Appl. Pharmacol. 2013, 267, 256-265. [CrossRef]

20. Jedidi, S.; Sammari, H.; Selmi, H.; Karim Hosni, K.; Rtibi, K.; Aloui, F.; OlfaAdouni, O.; Sebai, H. Strong protective effects of Salvia officinalis L. leaves decoction extract against acetic acid-induced ulcerative colitis and metabolic disorders in rat. J. Funct. Foods 2021, 79, 104406. [CrossRef]

21. Abdel Latif, Y.; El-Bana, M.; Hussein, J.; El-Khayat, Z.; Farrag, A.R. Effects of resveratrol in combination with 5-fluorouracil on N-methylnitrosourea-induced colon cancer in rats. Comp. Clin. Pathol. 2019, 28, s00580-019. [CrossRef]

22. Aebi, H. Catalase in vitro. Methods Enzymol. 1984, 105, 114-121.

23. Sun, Y.; Oberley, L.W.; Li, Y. A simple method for clinical assay of superoxide dismutase. Clin. Chem. 1988, 34, 497-500. [CrossRef] [PubMed]

24. Sedlak, J.; Lindsay, R.H. Estimation of total, protein-bound, and nonprotein sulfhydryl groups in tissue with Ellman's reagent. Anal. Biochem. 1968, 25, 192-205. [CrossRef]

25. Ohkawa, H.; Ohishi, N.; Yagi, K. Assay for lipid peroxides in animal tissues by thiobarbituric acid reaction. Anal. Biochem. 1979, 95, 351-358. [CrossRef]

26. Krawisz, J.E.; Sharon, P.; Stenson, W.F. Quantitative assay for acute intestinal inflammation based on myeloperoxidase activity. Assessment of inflammation in rat and hamster models. Gastroenterology 1984, 87, 1344-1350. [CrossRef]

27. Bird, R.P.; McLellan, E.A.; Bruce, W.R. Aberrant crypts, putative precancerous lesions, in the study of the role of diet in the aetiology of colon cancer. Cancer Surv. 1989, 8, 189-200.

28. Ranieri, G.; Passantino, L.; Patruno, R.; Passantino, G.; Jirillo, F.; Catino, A.; Ribatti, D. The dog mast cell tumour as a model to study the relationship between angiogenesis, mast cell density and tumour malignancy. Oncol. Rep. 2003, 10, 1189-1193. [CrossRef]

29. Zhou, X.; Xiang, X.; Zhou, Y.; Zhou, T.; Deng, S.; Zheng, B.; Zheng, P. Protective effects of Antarctic krill oil in dextran sulfate sodium-induced ulcerative colitis mice. J. Funct. Foods 2021, 79, 104394. [CrossRef]

30. Aviello, G.; Knaus, U. ROS in gastrointestinal inflammation: Rescue or Sabotage? Br. J. Pharmacol. 2016, 174, 1704-1718. [CrossRef]

31. Guazelli, C.F.S.; Fattori, V.; Ferraz, C.R.; Borghi, S.M.; Casagrande, R.; Baracat, M.M.; Verri, W.A. Antioxidant and antiinflammatory effects of hesperidin methyl chalcone in experimental ulcerative colitis. Chemico-Biol. Interact. 2020, $333,109315$. [CrossRef] [PubMed]

32. Wang, D.; Tian, L.; Lv, H.; Pang, Z.; Li, D.; Yao, Z.; Wang, S. Chlorogenic acid prevents acute myocardial infarction in rats by reducing inflammatory damage and oxidative stress. Biomed. Pharmacother. 2020, 132, 110773. [CrossRef] [PubMed]

33. Tian, S.; Chen, M.; Wang, B.; Han, Y.; Shang, H.; Chen, J. Salvianolic acid B blocks hepatic stellate cell activation via FGF19/FGFR4 signaling. Annal. Hepatol. 2021, 20, 100259. [CrossRef]

34. Li, Q.; Cui, Y.; Xu, B.; Wang, Y.; Lv, F.; Li, Z.; Li, H.; Chen, X.; Peng, X.; Chen, Y.; et al. Main active components of Jiawei GegenQinlian decoction protects against ulcerative colitis under different dietary environments in a gut microbiota-dependent manner. Pharmacol. Res. 2021, 170, 105694. [CrossRef]

35. Miyake, Y.; Tanaka, K.; Nagata, C.; Furukawa, S.; Andoh, A.; Yokoyama, T.; Hato, N.; Sayama, K.; Hiasa, Y. Dietary intake of vegetables, fruit, and antioxidants and risk of ulcerative colitis: A case-control study in Japan. Nutrition 2021, 91-92, 111378. [CrossRef] [PubMed]

36. Ozsoy, Z.; Ozsoy, S.; Gevrek, F.; Demir, E.; Benli, I.; Daldal, E.; Yenidogan, E. Effect of bevacizumab on acetic acid-induced ulcerative colitis in rats. J. Surg. Res. 2017, 216, 191-200. [CrossRef] [PubMed]

37. Wu, X.; Wang, L.; Tang, L.; Wang, L.; Cao, S.; Wu, Q.; Li, L. Salvianolic acid B alters the gut microbiota and mitigates colitis severity and associated inflammation. J. Funct. Foods 2018, 46, 312-319. [CrossRef]

38. Armuzzi, A.; Liguori, G. Quality of life in patients with moderate to severe ulcerative colitis and the impact of treatment: A narrative review. Dig. Liver Dis. 2021, 53(7), 803-808. [CrossRef] [PubMed]

39. Dziąbowska-Grabias, K.; Sztanke, M.; Zając, P.; Celejewski, M.; Kurek, K.; Szkutnicki, S.; Korga, P.; Bulikowski, W.; Sztanke, K. Antioxidant therapy in inflammatory bowel diseases. Antioxidants 2021, 10, 412. [CrossRef] 
40. Wang, R.; Diao, Y.; Kuang, W.; Li, Q.; Tian, Y.; Gao, J.; Wei, L. Salvianolic acid B alleviate the osteoblast activity decreasing under simulated microgravity by Keap1/Nrf2/ARE signaling pathway. J. Funct. Foods 2018, 46, 288-294. [CrossRef]

41. Krishnan, M.; Jayaraj, R.L.; Megala, J.; Elangovan, N. Antioxidant mediated antiulcer effect of Eupatorium triplinerve Vahl against acetic acid induced ulcerative colitis in mice. Biomed. Aging Pathol. 2014, 4, 153-160. [CrossRef]

42. Mariyappan, P.; Kalaiyarasu, T.; Manju, V. Effect of eriodictyol on preneoplastic lesions, oxidative stress and bacterial enzymes in 1,2-dimethyl hydrazine-induced colon carcinogenesis. Toxicol. Res. 2017, 6, 678-692. [CrossRef] [PubMed]

43. Arunachalam, K.; Damazo, A.S.; Macho, A.; da Silva Lima, J.C.; Pavan, E.; de Freitas Figueiredo, F.; de Oliveira Martins, D.T. Piper umbellatum L. (Piperaceae): Phytochemical profiles of the hydroethanolic leaf extract and intestinal anti-inflammatory mechanisms on 2,4,6 trinitrobenzene sulfonic acid induced ulcerative colitis in rats. J. Ethnopharmacol. 2020, 254, 112707. [CrossRef]

44. Pavan, E.; Damazo, A.S.; Arunachalam, K.; Othávio de Araújo Almeida, P.; Oliveira, D.M.; Venturini, C.L.; Tabajara de Oliveira Martins, D. Copaiferamalmei Harms leaves infusion attenuates TNBS-ulcerative colitis through modulation of cytokines, oxidative stress and mucus in experimental rats. J. Ethnopharmacol. 2020, 267, 113499. [CrossRef]

45. Novak, E.A.; Mollen, K.P. Mitochondrial dysfunction in inflammatory bowel disease. Front. Cell Dev. Biol. 2015, 3, 62. [CrossRef] [PubMed]

46. Zhang, J.; Zhen, Y.; Pu-Bu-Ci-Ren; Song, L.; Kong, W.; Shao, T.; Chai, X. Salidroside attenuates beta amyloid-induced cognitive deficits via modulating oxidative stress and inflammatory mediators in rat hippocampus. Behav. Brain Res. $2013,244,70-81$. [CrossRef]

47. Mitchell, P.; Moyle, J. Chemiosmotic hypothesis of oxidative phosphorylation. Nature 1967, 213, 137-139. [CrossRef]

48. Witaicenis, A.; Luchini, A.C.; Hiruma-Lima, C.A.; Felisbino, S.L.; Garrido-Mesa, N.; Utrilla, P.; Di Stasi, L.C. Suppression of TNBS-induced colitis in rats by 4-methylesculetin, a natural coumarin: Comparison with prednisolone and sulphasalazine. Chem. Biol. Interact. 2012, 195, 76-85. [CrossRef]

49. Jialing, L.; Yangyang, G.; Jing, Z.; Xiaoyi, T.; Ping, W.; Liwei, S.; Simin, C. Changes in serum inflammatory cytokine levels and intestinal flora in a self-healing dextran sodium sulfate-induced ulcerative colitis murine model. Life Sci. 2020, 118587. [CrossRef]

50. Lee, S.H.; Kwon, J.E.; Cho, M.L. Immunological pathogenesis of inflammatory bowel disease. Intest. Res. 2018, 16, 26-42. [CrossRef] [PubMed]

51. Dodda, D.; Chhajed, R.; Mishra, J. Protective effect of quercetin against acetic acid induced inflammatory bowel disease (IBD) like symptoms in rats: Possible morphological and biochemical alterations. Pharmacol. Rep. 2014, 66, 169-173. [CrossRef]

52. Gupta, B.; Das, P.; Ghosh, S.; Manhas, J.; Sen, S.; Pal, S.; Gupta, S.D. Identification of high-risk aberrant crypt foci and mucindepleted foci in the human colon with study of colon cancer stem cell markers. Clin. Colorectal Cancer 2017, 16, 204-213. [CrossRef] [PubMed]

53. Muthu, R.; Selvaraj, N.; Vaiyapuri, M. Anti-inflammatory and proapoptotic effects of umbelliferone in colon carcinogenesis. Hum. Exp. Toxicol. 2016, 35, 1041-1054. [CrossRef]

54. Furth, E.E.; Gustafson, K.S.; Dai, C.Y.; Gibson, S.L.; Menard-Katcher, P.; Chen, T.; Enders, G.H. Induction of the tumor-suppressor p16INK4a within regenerative epithelial crypts in ulcerative colitis. Neoplasia 2006, 8, 429-436. [CrossRef] [PubMed]

55. Boeckxstaens, G. Mast cells and inflammatory bowel disease. Curr. Opin. Pharmacol. 2015, 25, 45-49. [CrossRef]

56. Xie, Q.; Chen, X.; Zhang, M.M.; Huang, X.L.; Zhang, Q.; Zhou, J.Q.; Gan, H.T. Glial-derived neurotrophic factor regulates enteric mast cells and ameliorates dextran sulfate sodium-induced experimental colitis. Int. Immunopharmacol. 2020, 85, 106638. [CrossRef] [PubMed]

57. Wernersson, S.; Pejler, G. Mast cell secretory granules: Armed for battle. Nat. Rev. Immunol. 2014, 14, 478-494. [CrossRef] [PubMed]

58. He, S.H. Key role of mast cells and their major secretory products in inflammatory bowel disease. World J. Gastroenterol. 2004, 10, 309. [CrossRef] [PubMed]

59. Bischoff, S.C.; Krämer, S. Human mast cells, bacteria, and intestinal immunity. Immunol. Rev. 2007, 217, 329-337. [CrossRef] [PubMed]

60. Hamilton, M.J.; Sinnamon, M.J.; Lyng, G.D.; Glickman, J.N.; Wang, X.; Xing, W.; Krilis, S.A.; Blumberg, R.S.; Adachi, R.; Lee, D.M.; et al. Essential role for mast cell tryptase in acute experimental colitis. Proc. Natl. Acad. Sci. USA 2011, 108, 290-295. [CrossRef]

61. Talero, E.; Sánchez-Fidalgo, S.; de la Lastra, C.A.; Illanes, M.; Calvo, J.R.; Motilva, V. Acute and chronic responses associated with adrenomedullin administration in experimental colitis. Peptides 2008, 29, 2001-2012. [CrossRef] [PubMed]

62. Kurutas, E.B.; Cetinkaya, A.; Bulbuloglu, E.; Kantarceken, B. Effects of antioxidant therapy on leukocyte myeloperoxidase and $\mathrm{Cu} / \mathrm{Zn}$-superoxide dismutase and plasma malondialdehyde levels in experimental colitis. Mediators Inflamm. 2005, 2005, 390-394. [CrossRef] [PubMed] 